\title{
MEMORIAIS ESCOLARES E PROCESSOS DE INICIAC̣ÃO À DOCÊNCIA
}

\author{
Maria Aparecida Bergamaschi* \\ Dóris Bittencourt Almeida**
}

RESUMO: Neste texto, nos debruçamos sobre as narrativas de memória de 14 estudantes do curso de Pedagogia, bolsistas do Programa Institucional de Bolsas de Iniciação à Docência - PIBID. Os memoriais, que compõem o livro Iniciação à docência em Pedagogia: memórias que contam histórias, são analisados na perspectiva de compreendê-los como parte importante no processo formativo dos bolsistas que integram o programa, que desde o presente miram o passado e constroem memórias que revelam, principalmente, seus percursos escolares. Relendo cada memorial, retomamos também o processo de elaboração dos mesmos e o significado que adquiriram na formação de cada bolsista, destacando o que, coletivamente, apresentam como aspectos marcantes nas trajetórias de vida: a infância e a família, as experiências escolares e, por fim, a escolha da docência e o estar professor no PIBID.

Palavras-chave: Histórias de Vida; Memórias; Formação de Professores; PIBID.

\section{SCHOOL MEMORIALS AND TRAINING PROCEDURES TO TEACHING}

ABSTRACT: In this text, we analized the narrative memories of fourteen students from the Course of Pedagogy, scholarship holders of the Institutional Program of Iniciation to Teaching Scholarships - PIBID. The memorials that compose the book 'Iniciation to Teaching in Pedagogy: memories that count stories' are analyzed in the perspective to understand them as an important part in the formative process of the scholarship holders that integrate the Program, who from the present look into the past and construct memories that disclose their school passages. Rereading the memorials, we also resume each one of them and the meaning they have acquired in the formation of each scholarship holder, highlighting what they collectively represent as important aspects of their life trajectories: childhood, family, school experiences and, finally, the choice for teaching and being a teacher at PIBID.

Keywords: Life Histories; Memories; Formation of Teachers; PIBID.

\footnotetext{
*Doutora em Educação pela Universidade Federal do Rio Grande do Sul (UFGRS) e Professora da mesma Instituição; Coordenadora do PIBID-Pedagogia/UFRGS. E-mail: cida.bergamaschi@gmail.com

* *Doutora em Educação pela Universidade Federal do Rio Grande do Sul (UFGRS) e Professora da mesma Instituição; Coordenadora do PIBID-Pedagogia/UFRGS. E-mail: almeida.doris@gmail.com
} 


\section{CONTEXTUALIZANDO O PIBID}

Neste texto, analisamos as narrativas de memória de 14 estudantes do curso de Pedagogia da Faculdade de Educação da UFRGS, bolsistas do Programa Institucional de Bolsas de Iniciação à Docência (PIBID). Esses memoriais foram escritos ao longo do ano de 2011 com o objetivo de produzir o livro Iniciação à docência em Pedagogia: memórias que contam histórias.

Antes, porém, consideramos importante apresentar o PIBID. Trata-se de um Programa de Iniciação à Docência, instituído e financiado pela CAPES e que tem como principais objetivos valorizar o magistério, incentivar estudantes que escolhem a docência e elevar a qualidade da escola pública (COORDENAÇÃO DE APERFEIÇOAMENTO DE PESSOAL DE NÍVEL SUPERIOR, 2009). O PIBID/UFRGS conta com a cooperação da Secretaria de Educação do Estado, possibilitando a realização de ações didático-pedagógicas em escolas da rede pública estadual em Porto Alegre. Atuar na coordenação do PIBID nos entusiasma, principalmente pelas fecundas relações que mantemos com as escolas, e essa é uma forma de não rompermos os laços que nos identificam como professoras, uma forma de não nos apartarmos das referências que acompanharam e acompanham nossa vida profissional.

O PIBID pode ser definido como um projeto bonito e há motivos para assim qualificá-lo: primeiro, por promover uma intimidade com a escola, aproximando a docência dos alunos da graduação, por vezes, alunos que estão no início dos cursos de formação docente. Dessa forma, o Programa estabelece parcerias com a rede pública e colabora no desenvolvimento da formação continuada de professores, articulando os saberes das escolas e da universidade. Ambas, são formadas e formadoras: os estudantes das licenciaturas aprendem na e com a escola e os trabalhos que desenvolvem junto com seus orientadores têm também um papel formador. A escola entra no movimento de formação, pois, ao acompanhar os bolsistas que ainda são graduandos e ao participar de atividades propostas pelo Programa, os professores podem repensar suas práticas, no mesmo tempo em que atuam nos processos formativos dos estudantes das licenciaturas (COORDENAÇÃO DE APERFEIÇOAMENTO DE PESSOAL DE NÍVEL SUPERIOR, 2009). Importa dizer que o PIBID realiza práticas docentes vinculadas a ações investigativas, procurando estimular que os professores tornem-se pesquisadores, que percebam no estudo e na reflexão cotidiana de suas ações 
pedagógicas oportunidades de formação continuada. Em síntese, o PIBID promove ao aluno começar a se constituir como professor, colaborando na formação de jovens docentes.

Na execução das ações do PIBID Pedagogia UFRGS, os bolsistas desenvolvem o que chamamos de docência compartilhada. Superando o individualismo e possíveis conflitos, tanto o planejamento quanto as ações desenvolvidas acontecem no coletivo. Assim, embora sejam orientados tanto na universidade quanto na escola que os acolhe, não há protagonismo individual: um bolsista aprende com o outro, torna-se responsável pelo grupo, praticando a solidariedade no cotidiano da sala de aula. Esse exercício de docência faz pensar a profissão de professor, tradicionalmente solitária, faz pensar no quanto o trabalho em uma perspectiva coletiva é rico por oportunizar o crescimento de todos e, ao mesmo tempo, exigir comprometimento com a proposta educativa. A parceria entre universidade e escola objetiva que os bolsistas não se sintam desamparados, pois na faculdade há professoras que os orientam e, na escola, há uma supervisora responsável. A ideia de envolver professores no exercício da docência com a formação inicial dos licenciandos cria vínculos geracionais, pois os estudantes que aspiram à docência podem ter nesses professores em atuação uma referência, uma inspiração para sua futura profissão.

Por isso, entendemos que o PIBID precisa ser desejado pelas escolas parceiras. Buscam-se, assim, instituições de ensino que, de alguma forma, façam a diferença no contexto educacional, e, desse modo, despertem nos futuros professores o encanto pela docência.

Há outros impactos do programa que convêm destacar, tais como: a aprendizagem de conhecimentos de forma aprofundada que, por vezes, não acontece nas disciplinas da graduação ${ }^{1}$, o convívio com as realidades das escolas públicas e a experiência de construir juntos os caminhos do programa, estruturando formas conjuntas de abordar os conhecimentos. Isso faz com que a universidade estreite seus laços com algumas instituições de ensino públicas e as faculdades de educação cumpram seu papel como espaços de formação docente.

\section{O MEMORIAL: PERCURSOS DA ESCRITA}

As bolsistas ${ }^{2}$ do PIBID Pedagogia, sob nossa coordenação, foram desafiadas a narrar suas trajetórias de vida, produzindo, assim, um memorial 
em que privilegiaram suas vivências de escolarização, a escolha pela docência e o trabalho desenvolvido no referido programa.

A escrita autobiográfica constituiu-se em uma possibilidade de ressignificarem suas histórias de vida, a escolha da docência como caminho de formação, bem como a experiência proporcionada pelo PIBID. Em seus escritos fazem um balanço do vivido, procurando conferir sentidos à própria existência. Escreveram como um registro que se destina a uma perenidade.

Porém, como iniciar um processo de escrita de memoriais sem ao menos entender o que significa memória? Memórias são apenas lembranças? E aquilo que esquecemos já não faz mais parte de nossas memórias? Foi preciso estudar esse tema e fomos buscar compreensões na história. Memória, matéria-prima da história, é o "fio" que localiza a existência individual e coletiva no labirinto do tempo, que faz o elo entre as gerações, que dá sentido à ancestralidade e aos pertencimentos de cada pessoa e cada grupo no seu tempo e espaço. Estudando a história dos povos indígenas, inspiração primeira para cada bolsista revisitar suas origens familiares, refletimos sobre o quanto somos tributários dos povos originários da América. Daniel Munduruku (2002, p. 42), em um texto que clama pela busca de uma ancestralidade brasileira, pergunta: "Será que nossos educadores se preocupam em conhecer sua história de vida e ajudam os educandos a conhecer sua própria história?” Por esse caminho também estudamos as lembranças e os esquecimentos que compõem a memória e as teias de poder e disputas presentes em sua tessitura.

Precisávamos refletir mais e a literatura foi uma parceira nesse processo de buscar entender o que é a memória e trançar, com os fios da lembrança, cada um dos memoriais. Conversamos acerca da história de Guilherme Augusto Araújo Fernandes (FOX, 1995), um menino que convive com pessoas velhas, entre elas uma senhora chamada D. Antônia. Através dessa pequena narrativa, em que o menino descobre que memória é algo que se lembre, algo que faz rir, que faz chorar, que vale ouro..., vimos que nossas memórias não são espontâneas, precisam ser estimuladas, necessitam, portanto, de evocadores materiais, sensoriais... Cheiros, sons, imagens podem nos ajudar a lembrar... A leitura de Tecelina também contribuiu para desencadear o processo de escrita. Nas palavras da protagonista do livro, "[...] história é que nem fio: a gente tece e o fio cresce, a gente inventa e tudo o que a gente tenta se transforma em coisa nova." (SOUZA, 2002, 
p. 4). Somaram-se leituras de algumas partes de livros autobiográficos, como As pequenas memórias, de José Saramago, Alfabetto, a autobiografia escolar de Frei Betto, Meu avô Apolinário, de Daniel Munduruku, entre outros.

Buscando uma maior sensibilização, escutamos canções que de alguma forma remetiam ao tema das memórias e nos emocionamos com os versos de Lennon e McCartney "[...] desenhos que a vida vai fazendo, desbotam alguns, uns ficam iguais [...]”, choramos com a linda letra musical de Almir Sater e Renato Teixeira “[...] cada um de nós compõe a sua história, cada ser, em si, carrega o dom de ser capaz e ser feliz.”. E cada uma contou um pouco de suas histórias para o grupo, inspiradas pela canção Roda Viva, de Chico Buarque, representativa de uma época da História do Brasil, mas que também conduz à reflexão acerca da própria existência “[...] roda mundo, roda gigante, roda moinho, roda pião, o tempo rodou num instante, nas voltas do meu coração."3

Outra atividade que auxiliou no processo da escrita foi a leitura do livro Caminhadas de universitários de origem popular (WEBBER, 2006), produzido pelo Programa Conexões de Saberes: diálogos entre a universidade e as comunidades populares da UFRGS, pois nesse programa também houve o estímulo à produção de memoriais e, assim, as histórias de vida de 23 bolsistas do Conexões foram processualmente construídas e registradas, como uma estratégia de afirmação da presença de estudantes de origem popular na universidade. A leitura das narrativas desses estudantes promoveu identificações, pois cenas de vida relatadas no livro se aproximavam de situações vividas por nossas bolsistas do PIBID: a barreira representada pelo vestibular e a felicidade em rompê-la; as dificuldades de encontrar seu lugar na UFRGS, visto que o ensino superior historicamente foi um nível de ensino elitizado em nosso país; as dificuldades em remexer no "rio da memória” e deixar turvas as águas da lembrança de cada uma, que talvez também gostaria de deixar guardada no esquecimento algumas passagens da sua vida... Enfim, ler o Caminhadas foi significativo, pois perceberam a importância de produzir escritas que tornam perenes suas vivências e que se tornarão leituras necessárias para outras pessoas e para si mesmas em outros tempos. Cada uma das bolsistas do PIBID ficou responsável por ler ao menos uma história de vida do livro Caminhadas e depois refletíamos juntas sobre os efeitos dessa leitura, da importância de fazer com que as memórias produzidas registrassem a voz de estudantes de Pedagogia e os 
caminhos trilhados até chegar no curso que lhes licencia para a docência. E os labirintos da memória começaram a ser percorridos nesse ritual de encontro com outras narrativas, com outros personagens, com os quais se estabeleceram identificações e cumplicidades.

Entretanto, mesmo com todas essas discussões sobre memória, inicialmente a proposta não foi acolhida com grande satisfação por todos. Afinal, refletir, evocar e escrever sobre a própria vida é algo difícil, exige a disposição para penetrar nas camadas da memória, por vezes endurecidas pelas marcas que o tempo vai deixando. É preciso considerar o estranhamento de narrar as experiências passadas, não é fácil permitir-se parar em meio ao cotidiano que nos exige o atendimento a inúmeras demandas e dedicar-se a esse trabalho de rememoração e escrita. Nesse sentido, foram muitas as implicações nesse processo de escrita do memorial. Escolher o que contar, como contar, assumir os riscos de uma exposição pública são situações delicadas que foram discutidas ao longo da escrita e reescrita do texto.

Fomos em frente. Ainda permaneciam receios e resistências. Havia quem ainda não compreendesse o valor do livro e algumas vozes diziam: "Quem vai se interessar por nossos escritos?" "Ninguém vai querer ler." Momentos de inseguranças, de incertezas, de questionamento acerca da validade da produção do memorial. Entendemos que tais manifestações sejam também evidências de resquícios de uma formação escolar em que as pessoas ainda não se sentem partícipes da História, acreditam que somente sejam significativos as narrativas dos "grandes homens responsáveis por grandes feitos”. Então, promovemos uma reflexão sobre os sentidos da História, bem como explicitamos algumas concepções teóricas norteadoras do que se entende por História e por Memória na contemporaneidade, para que sentissem que valia a pena assumir esse desafio.

Em princípio, pareceu essencial uma compreensão mais fecunda acerca dos sentidos da memória, e concebê-la muito além da mera capacidade de lembrar os fatos passados. De acordo com o senso comum, pode-se pensar que as memórias referem-se àquilo que lembramos. Sim, a memória também é isso, mas é muito mais, as lembranças podem se apresentar como a ponta de um iceberg. Há um processo de interação entre os atos de lembrar e de esquecer. A memória é uma teia de subjetividades, por mais que haja imersão, por mais que se busquem evocadores, por mais que se evite a superficialidade, não há como atingir a totalidade daquilo que foi 
vivido no passado. Portanto, a memória constitui-se dos atos de lembrar e de esquecer, a um só tempo, e estes são produzidos socialmente. Como explica Bosi (2003, p. 18), "cabe-nos interpretar tanto a lembrança quanto o esquecimento". O exercício do lembrar não é em si um ato soberano, próprio de um sujeito autônomo e consciente. Há uma complexidade que permeia a evocação das lembranças, a produção dos silêncios e dos esquecimentos, complexidade que reverbera na elaboração dos memoriais como narrativas de vida: "Escrevemos e dizemos o que pensamos ter vivido, o que pensamos ter sentido, o que imaginamos ter experimentado [...]" (STEPHANOU, 2012, p. 11), pois é com as lentes do presente que olhamos para o passado. Rejeita-se, por conseguinte, a ideia da memória puramente individual, uma vez que não se pode desconsiderar o contexto vivido pelo sujeito que é "convidado" a pensar sobre o que viveu (SANTOS, 1993). A memória, portanto, também é coletiva, difundida e alimentada na convivência com os outros, produzida pelos discursos e pelas representações que propõem uma identidade ao grupo. Eclea Bosi (2003) dimensiona esse aspecto da memória, ao afirmar que são configurações mais fortes quando incide sobre elas um significado coletivo. Nesse sentido, os memoriais que analisamos são registros de trajetórias individuais, mas configuram lembranças pautadas por um significado coletivo: o caminho percorrido por jovens universitárias, e que tem em comum a escolha pela docência. São textos elaborados com fios coloridos que vão e vêm desde outros tempos vividos, fios que identificam um percurso pessoal, mas que, ao se juntarem num coletivo, compõem um novo tecido, arrematado pelas vivências e aprendizagens no Programa Institucional de Bolsas de Iniciação à Docência.

E quem são as pessoas que narram suas trajetórias pessoais, que elaboram seus memoriais? Ao considerar o grupo de bolsistas do PIBID Pedagogia nos reportamos aos sentidos dessas escritas, ao sentido coletivo desses passados recompostos: são relatos que trazem para o presente os processos de escolarização e a escolha pela docência. Há nesses relatos tão díspares e singulares algo que aproxima, que constitui um sentido comum e que diz de um presente compartilhado.

Toda a narrativa compreende certa fabulação, uma invenção da realidade vivida, ou, ainda, possui uma dimensão simbólica que leva a um certo desapego do real em busca do imaginário, sendo, antes de mais nada, um ponto de vista sobre algo (AMADO, 1995). Assim, o narrar não é algo 
absoluto, estático, mas depende muito de elementos articulados, tais como: "[...] quem narra, o que narra, por que narra, como narra, para quem narra, quando narra [...]”, afirma o autor (AMADO, 1995, p. 133).

As pessoas comumente constroem uma história sobre suas vidas. Thomson (2001, p. 86) complementa: "Construímos nossa identidade através do processo de contar histórias para nós mesmos - como histórias secretas ou fantasias - ou para as outras pessoas no convívio social.”. Ou seja, narramos aquilo que elaboramos acerca do que aconteceu, as lembranças são também reformuladas de acordo com as situações do cotidiano e com as emoções vividas, pois " [...] as histórias que relembramos não são representações exatas do nosso passado, mas traduzem aspectos desse passado e os moldam para que se ajustem às nossas identidades e aspirações atuais.” (THOMSON, 2001, p. 57).

Percebemos que todas essas reflexões ajudaram no processo da escrita; ao apropriarem-se dos significados do que é memória, conseguiram entender melhor os significados de arquivar fragmentos da própria vida em um texto. E foi assim que assumiram possíveis riscos da exposição, enfrentaram essa difícil tarefa, romperam o anonimato, e o livro Iniciação à docência em Pedagogia: memórias que contam histórias é o resultado de suas autobiografias. Escreveram a primeira versão, a segunda, a terceira... Nós professoras lemos, fizemos anotações, nos emocionamos com a riqueza, singularidade e fecundidade do que líamos, instigamos a escrever mais, sugerimos pensar melhor em algumas circunstâncias. Para que a leitura alcançasse outros leitores, cada uma escolheu entre o grupo um leitor fiel que fizesse uma imersão no texto e apontasse sugestões para a reescrita.

Neste exercício de escrita de si, cada autora e autor elaborou representações sobre si mesmos, misturaram-se nos textos acontecimentos pessoais, da escolha pela docência, da vida acadêmica, das aprendizagens oportunizadas pelo PIBID, das experiências da docência compartilhada. Ao lembrarem e registrarem suas lembranças, cada bolsista recolheu, organizou e reorganizou como num mosaico, algumas peças de sua memória, reconfigurando o tempo de vida ou a vida no tempo. Revelaram ao escrever suas múltiplas identidades, são mulheres, um homem, estudantes, filhas, algumas são mães, são pessoas com caminhadas diferentes, cada qual com suas histórias, crenças, valores e esses aspectos se fundem naquilo que foi eleito para ser contado. Como sugere Lovisolo (1989), as questões de memória 
têm a ver com nossos pertencimentos, com aquilo que imaginamos sobre nós mesmos, com nossos desejos, que vamos construindo, desconstruindo e reconstruindo ao longo da vida. Do mesmo modo, Fentress e Wickham (1992, p. 39) afirmam que "[...] a nossa experiência do presente fica, portanto, inscrita na experiência passada. A memória representa o passado e o presente ligados entre si e coerentes, neste sentido, um com o outro."

Assim, cada uma escolheu o que contar e como contar seus percursos. Escreveram sobre momentos felizes, falaram das lembranças da infância, enfatizaram as lutas para construir outras perspectivas de vida, valorizaram suas ancestralidades e suas redes de afetos. Significaram momentos marcantes da escolarização, descrevendo situações desafiadoras, como o vestibular para ingressar no curso de Pedagogia da UFRGS que, ao mesmo tempo, é percebido como obstáculo e vitória festejada pelas famílias. Buscaram na vida acadêmica os elos que ligam a docência numa cadeia de vivências e reflexões que dão sentido à sua formação. Remeteram suas lembranças a situações inspiradoras da escolha pela licenciatura que os encaminha para uma futura profissão e que no PIBID já começam a exercê-la como docência compartilhada, deixando transparecer nesses relatos o encantamento pela escola, amarrando no presente - e quiçá, projetando para o futuro - os fios que tecem suas lembranças.

Pela leitura de cada história, percebem-se as afinidades de cada autor, os percursos vividos em múltiplos lugares e traduzem uma busca pela maturidade em olhar para o vivido. Idas e vindas, chegadas, partidas, conflitos, alegrias, tristezas, perdas, conquistas tudo isso se mistura à escolha pela docência como ofício e se revela nos percursos trilhados que, compondo as narrativas apresentadas neste livro, traduzem as autorias ${ }^{4}$ de Orquídea, Bromélia, Açucena, Tulipa, Gérbera, Petúnia, Rosa, Espatodea, Dália, Girassol, Vitória- Régia, Margarida, Violeta e Cravo.

\section{PRIMEIRAS APROXIMAC̣ÕES: O QUE RE(DES)VELAM OS MEMORIAIS}

Foi preciso um tempo que permitisse certo distanciamento para retornar a esses escritos e olhar para o que cada um dos textos insistia em dizer. Era grande o desejo de voltar a eles, depois de formatados em livro, que teve direito a lançamento com seção de autógrafos em diferentes 
instâncias: oficialmente, no PIBID/UFRGS, junto com outras publicações do programa; em uma cerimônia acadêmico-afetiva, para os familiares, que compareceram à seção como a uma festa de formatura, celebrando a afirmação da autoria de filhas, netas, irmãs, esposas, mães; e, por fim, o evento que lançou o livro como recepção aos novos alunos da Pedagogia, que, além do livro autografado, tiveram a oportunidade de presenciar e participar de um ato de valorização da docência e, por conseguinte, de valorização de sua recente escolha.

Ao olharmos novamente os memoriais, fomos tomadas por surpresas ao nos depararmos com detalhes carregados de significados que, num primeiro momento, passaram quase despercebidos. É claro que nossa subjetividade aqui se faz presente, pois é grande o envolvimento com essas escritas e suas autoras, afinal convivemos com elas por quase dois anos, em quase todas as tardes. Elas nos permitiram conhecer e invadir suas vidas e, embora tenhamos feito isso com muito respeito, não é pouco. Agora é o momento de tomarmos esse material como fonte, como documentos para a História da Educação.

Assim, analisar os escritos dessas futuras professoras permite que suas narrativas sejam tramadas, produzindo algo como uma urdidura, uma "trama de relações" (BACHELARD, 1974, p. 322). Tomando esses referenciais, entende-se que é meditando o objeto que se tem a oportunidade de adensar a pesquisa. Na perspectiva bachelardiana, o espírito científico é essencialmente uma retificação constante do saber, que acaba por promover um alargamento dos quadros do conhecimento. O historiador elege os aspectos que considera relevantes na construção da sua teia de relações acerca do problema, o que rompe com a ideia de um passado organizado, contínuo, que esteja "aguardando" para ser desvelado e descoberto em sua totalidade.

Bachelard (1974, p. 250) também fala da necessidade de se estar constantemente estabelecendo relações entre o empírico e o racional, ou seja: “[...] se experimenta, precisa raciocinar, se raciocina, precisa experimentar [...]", pois é o ato de problematizar a realidade que direciona a construção de uma pesquisa, a empiria, por si só, não produz conhecimento. Assim, é importante "ler no simples o complexo", ir muito além das meras descrições, evidências, informações preliminares, ir além daquilo que se apresenta como imediato. 
No intuito de procurar compreender o que dizem os memoriais e os discursos enunciados pelos sujeitos, eis que se apresenta o momento de estabelecer relações entre os escritos das bolsistas do PIBID, construindo outros sentidos. Uma análise inicial permite entrever vários aspectos importantes das suas identidades: as histórias das famílias, seus deslocamentos na busca por trabalho, os papéis de pais, mães, avós na educação dos filhos, as marcas da escola atravessando as vidas dessas jovens, os lugares de onde vêm, a inserção precoce no mundo do trabalho, as lutas pelo ingresso na UFRGS, entre outros aspectos. Também nos mobiliza compreender o sentido atribuído ao PIBID em seus processos de formação.

Quem são essas 14 bolsistas do PIBID Pedagogia? Treze moças e um rapaz, cujas trajetórias de vida são sujeitos desta pesquisa, apresentados num primeiro panorama, com informações as quais consideramos fundamentais para melhor conhecê-los. O intuito é buscar pontos de aproximação ou de distanciamentos, a partir da observação e análise do que escolheram para dizer em seus memoriais.

Inicialmente, cabe dizer que apenas duas bolsistas viveram sua infância e adolescência na região central de Porto Alegre, as demais são provenientes das regiões periféricas da cidade, bem como da região metropolitana da capital. Essas duas bolsistas são as únicas que fizeram sua escolarização integralmente em escola particular, ambas estudaram na mesma escola de confissão católica localizada no centro da capital. As outras 12 bolsistas, autoras e autor dos memoriais, carregam marcas da escola pública, uma escolarização em muitos casos não linear, pois seis delas concluíram os estudos na modalidade de Educação de Jovens e Adultos, em idades mais adiantadas que as convencionadas para o ensino fundamental e médio.

A maioria das narradoras tem em torno de 20 anos de idade, uma delas tem pouco mais de 40 e quatro têm mais de 30 anos, isso evidencia que o ingresso na universidade não se deu, para muitos, de forma linear como uma consequência natural da escolarização após a conclusão do ensino médio. Sete delas são casadas e três são mães, uma tem um filho, outra tem dois filhos, e ainda outra foi mãe aos 16 anos. Uma das bolsistas tem concluído o curso de Fisioterapia, três vivenciaram, mas não concluíram, experiências em outros cursos de graduação. Para muitas, parecia distante de seus horizontes a possibilidade de estudarem na UFRGS, pois o mundo do 
trabalho e a necessidade de sobrevivência as absorvia quase completamente. Talvez isso explique a ênfase na escrita ao processo que lhes permitiu ocupar uma vaga no curso de Pedagogia da Universidade Federal do Rio Grande do Sul.

Em relação às inserções no mundo do trabalho, têm-se situações bem diversas: apenas três não tiveram experiência profissional antes do ingresso na universidade, quatro trabalharam no comércio, uma ainda é recreacionista em festas infantis, três das narradoras, mesmo sem formação pedagógica, trabalharam em escolas de educação infantil e duas desenvolveram trabalhos de iniciação científica na universidade.

Depois de estudar cada texto, buscando aproximações e distanciamentos entre eles, foi preciso organizar e sistematizar as diferentes ideias e informações que cada um fornecia. Assim, a partir da leitura do que foi dito, do que foi sistematicamente evocado, do que foi escolhido para ser contado no memorial, acompanhando o fluxo das rememorações, foram pensadas algumas possibilidades de análises como tentativas de mirar com mais cuidado os temas que se apresentaram recorrentes nos escritos, bem como as peculiaridades suscitadas por cada um, no sentido de melhor conhecê-los. Elegeram-se os temas lembranças de infância, vivências familiares, experiências escolares, escolha pela docência e atuação e aprendizagens no PIBID, desdobrados nos itens que seguem.

\section{LEMBRANC̣AS DE INFÂNCIA E VIVÊNCIAS FAMILIARES}

Os temas da infância e da família ocuparam boa parte das páginas de cada memorial. Afinal, como pensar na trajetória pessoal sem discorrer sobre o início de nossas vidas? Como narrar a própria existência sem incluir rememorações que incluem aqueles que nos educaram primeiramente? Há, nesses relatos, um intento de mostrar os pertencimentos, o fio que liga gerações, o tecido colorido, contínuo e transformado, trançado em pedacinhos, às vezes com pontos do avesso, para mudar o sentido do tramado, como diz Tecelina (SOUZA, 2002).

Talvez as razões para essa avalanche de memórias que remetem à infância também estejam associadas aos padrões vigentes na sociedade em que o modelo de família nuclear ainda é um paradigma. A modernidade 
promoveu essa constituição familiar e, neste contexto, a afetividade passa a ter uma importância gradativamente maior nas relações sociais e familiares.

Ao nos debruçarmos sobre o que dizem a respeito das famílias, observamos que várias narrativas evidenciam que o trabalho dos pais e avós esteve ligado à agricultura. De modo geral, nota-se uma mobilidade espacial nos itinerários de muitas famílias, explicitadas nas histórias que contam a vinda dos pais de cidades do interior para a capital, em outros mudaram-se de estado e uma narrativa conta as migrações, inicialmente do Brasil para Argentina e, depois, para o Brasil novamente. A busca pelo trabalho, por melhores oportunidades de vida moveu essas pessoas que transitaram de um lugar para outro. Há histórias que representam os rumos da economia e da sociedade brasileira na segunda metade do século XX, ou seja, o processo de expulsão do campo e consequente migração da zona rural para as cidades.

O pai e a mãe da garota já tinham ido morar em Florianópolis. Ela aprendeu muito quando morou sozinha, pois toda aquela dependência que ela tinha da mãe estava sendo superada por momentos de grande autonomia. (Gérbera)

Logo após o período que moramos com minha avó, meus pais resolveram retornar a sua casa na Argentina e, assim, boa parte da minha infância foi vivida na cidade de Buenos Aires, até exatamente a idade de sete anos. Este período foi muito significativo em minha vida. Meu pai era taxista e minha mãe, embora formada em Pedagogia, se dedicou a cuidar dos filhos por mais de dez anos. (Bromélia)

Naquela época era comum um casal ter vários filhos, não havia planejamento familiar, e sim o contrário: como meus pais são filhos de agricultores o costume era ter muitos filhos, para ajudar na lida do campo. Porém eles já não moravam mais no interior, era uma nova realidade e eles teriam que se adaptar a ela. (Petúnia)

Embora a maioria dos bolsistas seja bastante jovem, ainda assim, ao descrever as relações familiares, o pai, muitas vezes, é definido como sendo o provedor da família e a mãe como uma pessoa que abriu mão de muitas coisas, para cuidar de todos.

Como meu pai trabalhava bastante para sustentar a família e nos dar o conforto que ele não teve, minha mãe não trabalhava e dedicava-se às filhas. Tive colégio bom, ganhava presentes, fazia atividades extra-classe como inglês e ballet, ou seja, usufruía dos recursos que o trabalho árduo do meu pai nos proporcionou em detrimento de suas ausências. (Girassol) 
Minha mãe é um referencial de mulher batalhadora e guerreira. Que me serve de inspiração e exemplo, e que me apoia até hoje. (Rosa)

Nas histórias de vida analisadas, há dois conceitos que se entrecruzam como legado da família: educação e trabalho. Em algumas narrativas, o valor do trabalho aparece como prioridade, por exemplo, nas palavras de uma das bolsistas que declara um dos ensinamentos que seus pais lhe deixaram: "para conseguir as coisas tem que trabalhar". Assim, a atividade laboral é fundamental, entendida como necessidade para a sobrevivência.

De modo geral, essas jovens estudantes já ultrapassaram a escolaridade dos pais, por isso uma fala recorrente diz: "meus pais dizem que a educação é a melhor herança" e, quem sabe, promotora de ascensão social. Pais e mães, por diferentes motivos, são percebidos como grandes incentivadores ao estudo dos filhos, seja porque lhes faltou essa oportunidade, seja pelas efetivas dificuldades em concluir um curso superior.

Penso que essa forma avessa de incentivar os estudos seja pela infância pobre e difícil que ele vivenciou, sendo o primeiro da família a ter curso superior com a ajuda da empresa em que trabalhava na época, ou seja, porque desejava uma vida confortável para mim. (Açucena)

Se hoje cheguei até aqui, é porque ela me incentivou muito e, mesmo que não tenha tido as mesmas oportunidades que tive para estudar - começou a trabalhar com seus pais quando ainda era criança - apostou na importância dos estudos para o futuro de seus filhos. (Rosa)

Ao ler cada história nessa perspectiva, nos deparamos com lembranças doloridas, o modelo imaginado de família ocidental na maioria das vezes não corresponde à vida real, em que as composições familiares são múltiplas e conflituosas. Relações entre pais, mães, filhos são conflituosas por natureza, marcadas por embates, e isso se afasta do estereótipo da idealização familiar em que todos parecem ser felizes com seus lugares definidos. Há narrativas que deixam claras situações de abandono, impedimentos na criação dos filhos, perdas, tensões enfrentadas no cotidiano.

Entretanto, algo bonito que comparece em mais de um memorial é a presença dos avós e sua constância na educação das netas. Em mais de um caso, o convívio com os mais velhos foi fecundo, proporcionado 
também pelo fato de morarem todos juntos. Uma das moças teve como única referência de família a avó, com quem viveu seus nove primeiros anos:

Chegou o tempo de entrar na escola, e fui, ainda pelas mãos de Dona Nadir. O boletim era repleto de "AS" o que enchia minha avó de orgulho. [...] Esses foram os melhores anos da infância. Morávamos em uma casa com um pátio bem grande, cheio de árvores frutíferas, brincava bastante e fazia muita "arte", como minha vó costumava dizer. Quando penso nessa época e em minha avó, lembro que dormíamos em camas separadas, porém passávamos a noite toda de mãos dadas e tenho a certeza do amor incondicional que mantínhamos mutuamente. (Margarida)

Tenho lembranças boas de alguns momentos vividos no primeiro lugar que morei: meu avô me chamando de "princesinha", quando assistia Roque Santeiro ao lado de minha avó, quando um terço podia servir não só para a fé católica, mas para diversas brincadeiras, da primeira boneca que ganhei deles, da comida da minha avó, principalmente o toucinho que ela fazia e minha mãe brigava comigo quando sabia que eu comia, do café da tarde em que eu botava muito açúcar. (Dália)

A infância é percebida como uma época feliz, de encantamento, o que pode ser evidenciado em várias narrativas:

Uma infância muito feliz. Com muita diversão, amigos de condomínio, férias na praia, passeios, viagens, brinquedos e brincadeiras. (Girassol)

Lembro-me do meu pai e eu, aos finais de semana, na pracinha perto de casa; lá eu corria, subia em árvores - aliás, eu tinha a minha própria árvore -, jogávamos futebol, brincávamos de herói, de monstro e princesa... Enfim, voltávamos para casa com as roupas sujas de tanto correr e cair no chão. Já com minha mãe as brincadeiras eram outras: brincávamos de escola, de boneca, de desenhar e de jogos. (Tulipa)

Talvez tudo isso que vivi até agora tenha sido, ou melhor, "foi" por causa da criação que tive dos meus pais. Eu e minha irmã fomos criadas com liberdade, sempre nos incentivaram para as artes lembro sempre ganhávamos tintas e massinhas coloridas. Eu e minha irmã criávamos um universo à parte, cheio de cores e formas ao som das historinhas e músicas dos discos de vinil. (Vitória-Régia)

Ao produzirem o memorial, cada bolsista ressignificou suas memórias, conseguiu, a seu modo, refletir sobre sua vida, uns mais, outros 
menos, mas todos estiveram de alguma forma implicados naquilo que escolheram para contar e, assim, conseguiram melhor avaliar o vivido. Nesse sentido, especialmente entre aquelas que são mães ou são mais velhas, percebe-se que conseguiram demonstrar uma postura que talvez se possa dizer de maior maturidade ao avaliarem o valor dos pais no seu processo educacional.

Meus pais dizem que a educação é a melhor herança que podem nos deixar, com essa afirmação, talvez estejam se referindo a uma educação escolar, eu concordo com eles, mas devo acrescentar ao conceito de educação os valores que eles me ensinaram. (Orquídea)

Meus pais casados há trinta e cinco anos cultivaram valores em nossa formação humana, acredito que por tal razão, hoje sou uma pessoa solidária, simples e correta. A educação que recebi deles foi fundamental na construção de minha identidade, tanto pessoal quanto profissional. Somos unidos desde sempre, eu, meus pais e minhas duas irmãs. (Girassol)

No estudo sobre estudantes de origem popular na universidade, realizado por Arenhaldt (2012), também aparece muito forte a presença definidora das famílias nas trajetórias escolares desses universitários. Em todas as histórias de vida consideradas pelo pesquisador, a família aparece como uma rede de amparo, com papel destacado na formação do estudante como pessoa, corroborando com o que aparece na quase totalidade dos memoriais dos estudantes de Pedagogia que ora consideramos.

\section{EXPERIÊNCIAS ESCOLARES}

A escrita do memorial teve a intencionalidade de provocar a reflexão sobre si, valorizando, nesse sentido, as vivências escolares. Assim, esses futuros professores começam a constituírem-se enquanto docentes, identificando as marcas de seu processo de escolarização. "A escrita de memoriais se constitui em um dispositivo valioso no sentido de entender como aprendemos a ser professor e a viver a escola [...]", dizem Arenhaldt e Marques (2010, p. 17).

O primeiro aspecto que chama atenção é a recorrência a tristes lembranças com relação à vida escolar. Por que será? Observam-se narrativas 
que evidenciam práticas punitivas e medo dos professores. A escola, um lugar tão repleto de gente e de vida, nas lembranças de algumas bolsistas, é evocada como um lugar em que se sentiam profundamente sós.

Minha vida escolar do pré ao último ano do segundo grau foi sem graça, chata, triste, solitária... Na lembrança ficaram cobranças, regras, limitações, grupos, turmas, líderes, marcas, aparência, visual, estereótipos. Enfim, considerava-se o externo das pessoas, seu sobrenome, seu status, sua fama... (Girassol)

O ensino fundamental não foi muito gentil comigo: nunca tive roupa de marca, mas sempre fui bem vestida, não namorava igual as outras meninas, não saía sozinha com amigos e minha merenda não era tão legal quanto um ruffles dos outros colegas. Eu só sentia saudades de Buenos Aires onde era a melhor da sala e reconhecida na escola. (Bromélia)

Sempre tive problemas de convivência, principalmente na escola. Um dos motivos era por eu ser tímida, quieta e também por ter estudado em uma escola particular e não ter o nível social da maioria dos alunos. No ensino fundamental, sempre passava os recreios sozinha... (Dália)

Minha primeira experiência escolar não foi muito boa. A $1^{a}$ série na escola foi assustadora, eu tinha muito medo da minha professora ao qual lembro, pois ela gritava e pulava na sala. Ao invés de me aproximar dela acabei me afastando, ficava tensa quando queria ver os cadernos, e tentava não chamar sua atenção. Aos mais bagunceiros ela castigava, os colocava em pé atrás da porta ou ficavam sem recreio. Fiquei cada vez mais calada e quieta, tentava brincar com meus colegas, mas eles me excluíam de todas as brincadeiras. Na hora do recreio ficava sozinha sentada num canto, às vezes falava com outras crianças que eram também excluídas por eles. (Petúnia)

Minha expectativa da escola era muito grande, pois imaginava um mundo só de crianças, onde havia diversão, brincadeiras, amizades... No momento que entrei no ambiente escolar, tive um choque com o sistema de regramento e várias dificuldades de relacionamento com os colegas. (Cravo)

Essas moças e moço, estudantes da Faculdade de Educação, talvez consigam avaliar com conhecimento pedagógico os significados de estar na escola, os temores, anseios, a decepção e as dificuldades de ser aceito no espaço escolar, pois ao longo da formação acadêmica a instituição escolar é estudada sob variados vieses. Mostram em suas escritas as marcas, nem sempre positivas que a escola produz, como um lugar que prioritariamente, 
apaga e invisibiliza a criança que, ao adentrar nos portões da escola, se transforma em aluno, como constata Cravo: ao ingressar na escola "imaginava um mundo só de crianças, onde havia diversão, brincadeiras, amizades...”. No entanto, predomina um mundo de regramentos, impondo padrões de conduta, tempos e espaços homogeneizados, medidos e controlados. Assim é a escola instituída na modernidade ocidental, não apenas um lugar para aprender conhecimentos, mas também um lugar para constituir a subjetividade regrada, formatada e homogênea.

Podemos tomar como exemplo a homogeneidade temporal que vem marcando progressivamente a escola e hoje está quase que naturalizada numa rotina regrada, com atividades contínuas distribuídas nas horas das manhãs e das tardes, marcando o ritmo da vida inclusive fora da instituição, pois o tempo da escola se transformou em referência para a vida das crianças. Igualmente podemos falar dos espaços que, durante longos períodos do dia, confinam as crianças entre as paredes da sala de aula, impedindo-as de realizar atividades lúdicas, tão importantes e desejadas pelas crianças, como imaginava Cravo, mas que na instituição precisam se comportar como alunos.

Ao mesmo tempo em que a escola padroniza, lida com um ideal de pessoa e de criança-aluno, as diferenças se transformam em desigualdades socioeconômicas, sobressaindo o comportamento e os elementos materiais dos que, imaginariamente, possuem melhor merenda, melhor roupa, melhor posição social, melhor sobrenome. O sentimento de inferioridade produzido nas relações comparativas e classificatórias que predomina na escola, em geral, acompanha estudantes de baixa renda, e muitas diferenças que poderiam potencializar a sala de aula como um espaço das pluralidades do existir humano formam estereótipos: tímida, quieta, bagunceira...

Os excertos dos memoriais que evidenciam marcas nem tão agradáveis assim da escola nos fazem pensar o quanto essa escrita é também formadora dos professores do amanhã, hoje bolsistas do PIBID. Retomando as vivências escolares, essas jovens, futuras docentes, podem se dar conta das marcas que a escola produz e não foram poucas as vezes que os escutamos desabafar: "Eu não quero ser assim quando for professor!” As experiências escolares podem reverberar em repetições, reproduzindo práticas análogas com seus alunos como, aliás, ocorre na maioria das vezes. Porém, diante de situações reflexivas como a produção do memorial, há a possibilidade de ressignificações, como diz Dália nesse trecho de seu memorial: 
Por experiência própria vejo que o professor deixa marcas, positivas ou negativas, até a vida adulta de uma pessoa, por isso deve haver essa reflexão constante por parte do professor. Se alguns professores em minha infância tivessem tido essa sensibilidade comigo de ver as minhas peculiaridades e saber lidar com isso, creio que teria sido mais fácil para eu lidar com algumas questões.

No entanto, na leitura dos memoriais encontramos também muitas lembranças alegres, que mostram as marcas das experiências prazerosas, inclusive inspiradoras para a escolha da docência:

Sempre fui ótima aluna e gostava de ir à escola, tirava notas boas e sempre passava de ano. Quando alguém me perguntava o que eu gostaria de ser quando crescesse, eu dizia que queria ser professora. (Espatodea)

No primeiro dia de aula, a professora foi na porta, onde havia algumas mães, e perguntou quem era a mãe da pequenininha que estava chorando. Como estava acostumada a passar todos os dias em casa com a minha mãe, estranhei aquele lugar estranho. Mas, aos poucos, fui me adaptando, construindo amizades e o ambiente foi se tornando agradável e familiar, pois sempre gostei muito de conversar como o meu avô, e isso me ajudou a minha socialização nos diversos grupos que frequentei até hoje. (Açucena)

A escola para mim, em grande parte do tempo, foi um lugar de diversão. Talvez por isso minha escolha por ser professora. Ao entrar no ensino médio a diversão, dentro da sala de aulas, já não era mais tão divertida; surgiram matérias como Física, Química que me assustavam, além da Matemática tomar contornos extremamente complexos, os quais eu não conseguia acompanhar. Contudo, as ciências humanas continuavam sinônimo de prazer para mim. Ao entrar na adolescência, meu gosto literário foi formando-se, e as histórias de conto de fadas deram lugar às histórias da História. (Tulipa)

Do ensino fundamental, devo dizer que essas não foram as únicas lembranças, pois tenho outras lembranças muito boas também. Nessa escola, onde fiz a primeira e a segunda série, assistíamos a peças de teatro dos alunos da escola e de outras escolas também. Tinha festa junina - a quadrilha era esperada o ano inteiro: dançar com um coleguinha de mãos dadas era um grande evento. Tive boas professoras e colegas que eu gostava muito. (Vitória- Régia)

Há uma narrativa especialmente bela, pois mostra as diferenças entre as vivências na escola pública e na escola particular. Do ensino fundamental, frequentado em uma instituição de ensino privada, restaram lembranças de uma escola que não respeitava as individualidades, insistia em um formato de acordo com um modelo estereotipado de ser um bom aluno. 
A marca que eu trago desde a minha infância é a timidez. Na escola fui muito visada por ser introvertida e as pessoas em geral não aceitam essa característica. As pessoas com as quais tive contato tanto na escola quanto na família nunca entenderam minha timidez como característica e sim como problema. Sempre enfatizaram essa característica no intuito de mudá-la, dizendo que eu tinha que me expressar, falar, até que um dia cansei e, em uma aula de História, resolvi falar, mas não falei na hora em que a professora gostaria. (Dália)

Entretanto, no ensino médio, a aluna migrou para uma escola pública e ali descobriu as alegrias da vida de estudante, valorizou sua autoestima e, naquele novo espaço, a timidez passou a ser respeitada pela instituição e seus professores:

Lá conheci colegas e professores que me fizeram ter outra visão de escola e até de mundo. Lembro-me do primeiro dia de aula, aula de Artes: sentei-me na frente do quadro-negro e, por causa disso, espirrei acidentalmente, meu nariz sangrou, tive que sair da sala... Quando voltei encontrei em cima de minha classe um pacote de lenços de papel que a professora havia deixado. Esse pequeno gesto me mostrou muito mais que qualquer discurso, me mostrou preocupação, me mostrou gentileza, esse gesto de alguma maneira mudou algo dentro de mim. A partir desse momento, pude constatar o quanto um professor pode modificar a vida de um aluno com um simples gesto.

$\mathrm{Na}$ escola, aprendi o alfabeto, equações, mapas; aprendi a conviver, a errar, a fazer, a gostar, a perdoar, a sentir, a viver. Muitos professores que tive me fizeram ver o valor dessa profissão, cada um de uma forma, mas todos mostrando o amor que tinham ao exercer sua função de professor. Uma me mostrou isso através de seu empenho em me ensinar Matemática, outra na sua preocupação com meu bem-estar, outra por buscar formas alternativas de ensinar, através da música, por exemplo... outra por me ouvir ao apresentar um trabalho sozinha e me apoiar, outra por me mostrar que eu era capaz. (Dália)

Em tempos de tamanho descrédito do ensino público, ler esse depoimento é comovente. Muitas vezes afogados em um cotidiano que impõe ritmos de trabalho absurdos, determinadas atitudes, tão singelas, podem passar despercebidas entre os docentes e suas ações marcam as pessoas que estão formando, positiva ou negativamente. O exemplo citado por Dália dos lenços de papel pode parecer banal, prosaico, mas tem um conteúdo forte que pode ter mostrado à estudante os caminhos da profissão docente. Assim, ela consegue fazer uma síntese de tudo que aprendeu com os professores dessa escola, cada um a seu modo, a ajudou em seu processo formativo. 


\section{A ESCOLHA DA DOCÊNCIA E O ESTAR NO PIBID}

Contando seus caminhos percorridos, as estudantes revelam como a docência aparece em seus horizontes. Das 14 histórias de vida, seis revelam que já tinham experiência de escola ou de trabalho com crianças antes de ingressar no curso de Pedagogia. "Por que resolvi ser professora?" se pergunta Girassol e, ao mesmo tempo, responde: "Por um ideal, pela utopia, por algo que busco e acho que só ao compartilhar conhecimentos é possível acontecer, crescermos enquanto pessoas. Ensinando respeito, doando afetividade, transmitindo valores e integridade". São belos os relatos em que aparece a escolha pela docência, mesmo quando contada em tom de queixa, como escreve Orquídea:

Muitas vezes eu me perguntei porque demorei tanto para descobrir o que eu queria fazer. Se eu tivesse escolhido o curso de Pedagogia logo que saí da escola eu já poderia estar formada. [...] Gosto de pensar que talvez tenha sido melhor assim. Que talvez eu não estivesse pronta, ou madura o suficiente. Que precisasse de todas as vivências e experiências que tive para poder aproveitar e poder dar o devido valor ao curso e a essa profissão, como hoje eu faço. Acredito que os fatos em nossas vidas acontecem no momento certo para acontecerem, assim tem sido para mim.

Trechos dos memoriais, por vezes dramáticos, revelam a conquista que representou o vestibular e como essa conquista se trança no processo da escolha pela Pedagogia.

O ano passado, com o incentivo de meu esposo e da mãe dele, resolvi prestar o vestibular, para testar meus conhecimentos e ver o que ainda conseguia lembrar-me do aprendido no colégio e então traçar uma estratégia de estudos a partir daí para o vestibular. Então chegou o dia do resultado, janeiro de 2011, 16 horas, estava sozinha no meu serviço e então abri o site da UFRGS, fui até a letra "S" tremendo, corri a barra de rolagem atropeladamente, comecei a enxergar várias "Simones" e já estar quase conformada, quando um "Silva da Silveira" pulou no meu olho, esfreguei bem ele e olhei de novo pra ter certeza... E era eu mesma, o curso de Pedagogia, $1^{\circ}$ semestre. (Margarida).

Tentei vestibular na UFRGS por quatro anos e passei na Pedagogia em 2009 e me identifiquei muito com o curso. [...] Muitas vezes me perguntava se fiz certo em ter entrado tão tarde para a universidade, tendo me dedicado por tanto tempo à capoeira. Na verdade, agora percebo que fiz a escolha certa. Talvez eu não aproveitasse tanto o curso da Pedagogia se não tivesse vivido o que vivi e conhecido e estudado a capoeira durante esse tempo. (Vitória-Régia). 
No ano seguinte, decidi que faria vestibular para Pedagogia, para que eu pudesse aprender a ensinar, afinal já tinha como certo a decisão de ser professora. [...] passei o ano estudando e, consegui a minha aprovação na Universidade Federal do Rio Grande do Sul, eternizando aquele janeiro de 2011 em um momento de grande felicidade a mim e os meus familiares. Ao iniciar a faculdade dei-me conta de que fiz a escolha certa; a cada aula me vejo mais encantada com o estudo sobre a mente e universo infantil. (Tulipa)

Bromélia e Petúnia reafirmam o quão difícil é ultrapassar a barreira do ingresso: "Cheguei egressa de escola pública, entrei no segundo semestre de 2008, algumas dificuldades ao me acostumar no ambiente acadêmico, porém sempre confiante." "Na segunda tentativa de passar na UFRGS, estudei muito mais do que na primeira vez, me dediquei ao máximo e dessa vez eu consegui passar no vestibular."

Pensando na escolha pela docência, talvez, não exista um momento específico, mas na escrita de Gérbera aparece algo recorrente nos memoriais: ser professora já era uma prática ensaiada nas brincadeiras de criança, que recorda, constrói como lembranças de sua infância. Ou então como narra Açucena, que não sabia explicar muito bem o porquê da escolha.

Somente agora, neste momento, ao fazer o exercício de reflexão para escrita da minha história de vida, mergulhada em minhas memórias, é que pude perceber que a minha escolha não foi inconsciente e muito menos ao acaso. Foi fruto de uma ancestralidade que também se constitui em parte por docentes: bisavó, primos de meus pais, filhos dos primos de meus pais...

A experiência no PIBID aparece quase que como um divisor de águas na relação com a licenciatura e com a docência, afinal, todas sentiram na prática o estar professora, como "experiência única" de "convívio com a realidade escolar e com a docência compartilhada" ou a "sensação de plenitude daquele momento, em ouvir pela primeira vez uma criança me chamando de professora", como poeticamente foi registrado nos memoriais. Além de compreendermos o quão formativo foi o processo de elaboração dos memoriais, eles também nos dão elementos para a compreensão do próprio programa e das ações que desenvolvemos no PIBID Pedagogia. Como afirma Petúnia: "Estou a cada dia aprendendo a ser professora, entendendo um pouco mais do universo escolar, indo nas escolas para realizar na prática a 'iniciação à docência', a fazer o planejamento, a ter 
os dias de leitura e formação". Ou nos múltiplos depoimentos que não nos furtamos em compartilhar, pois evidenciam a riqueza das vivências, mostradas como reflexões nos memoriais:

Quando fui selecionada para entrar no grupo de 15 bolsistas do PIBID para trabalhar em uma das escolas que o PIBID atendia, ficava me perguntando sobre o que faria nesta bolsa, pois era um programa novo que a recém estava se constituindo na Universidade, e na Pedagogia. O PIBID faz pensar a cada instante sobre o processo de constituição como professora-pesquisadora. (Gérbera)

A experiência na escola foi gratificante, desafiadora e, muitas vezes, angustiante, pelo desafio. Além disto, o compartilhar conhecimentos e saberes com todos os indivíduos do programa, incluindo bolsistas e coordenadoras foi importante na minha formação. A socialização, as relações interpessoais podem despertar sentimentos e sensações variadas, assim como comportamentos e posturas, os quais nós desconhecemos. Expor nossas qualidades e defeitos é mostrar um pouco de nós, assim como reconhecer no Outro as nossas características, que em alguns momentos gostaríamos de ignorar, mas não podemos, pois é preciso encarar e trabalhar as diferenças sempre. (Girassol)

...compartilhei experiências que proporcionaram aprendizagens inesquecíveis, como a importância da escuta sensível, deixar que as pessoas se expressem, pois cada um tem suas singularidades. Durante o trabalho desenvolvido pude resgatar também minha cultura, tendo orgulho de minha ancestralidade indígena e afrodescendente. (Bromélia)

Tem sido um dos trabalhos mais significativos para mim, proporcionando estudo, pesquisa e atuação docente e compartilhada. No PIBID recebi toda uma formação sobre temática indígena e afro-brasileira e sobre memória histórica que irão permear as minhas futuras práticas-pedagógicas. $\mathrm{O}$ trabalho de docência compartilhada, fundamental para me ver no outro e aprender com ele, planejar junto, compartilhar estudo, turmas, não dividindo, e sim somando. (Açucena)

Em nossas idas à escola, aonde o projeto é desenvolvido, é possível sentir o afeto verdadeiro que vem das crianças, a felicidade que eles demonstram em estar conosco. Certo dia, ao chegarmos à escola notei que um grupo de meninas estava brincando, aproximei-me e perguntei do que brincavam. A resposta foi surpreendente, disseram-me que estavam brincado de "professoras do PIBID"; então uma das meninas disse: "Eu sou tu, a Júlia do PIBID”. Foi um momento muito emocionante para mim, pois percebi a representatividade que temos na vida de nossos alunos. (Tulipa) 
E, mostrando a vida do grupo, aparecem também conflitos, pois como diz Marceli: "Quinze bolsistas, iniciando a docência com histórias bem diferentes, tornam os dias muito tumultuados". Mas, acima de tudo, os relatos mostram que "ser professora é muito mais do que ensinar e aprender. É conviver com a alegria, a insegurança, a espontaneidade, a transparência, o carinho, os conflitos, a sabedoria, e muitos mais adjetivos, das crianças, dos adolescentes e dos adultos", como escreve Espatodea.

\section{CONCLUSÕES}

Neste texto, produziu-se um estudo reflexivo acerca das narrativas de memória de bolsistas do PIBID, estudantes do curso de Pedagogia da Faculdade de Educação da UFRGS, em que cada um construiu o seu memorial, desenvolvendo composições singulares de suas trajetórias de vida.

Ao olharmos para esses escritos, nos interessaram os detalhes, as idiossincrasias, aquilo que poderia parecer prosaico. Assumiram relevância os aspectos mais singelos, que, em uma perspectiva tradicional, poderiam parecer folclóricos ou sem significado. As informações, que aparentemente pareciam ser banais, adquiriram repercussão neste estudo, investindo o presente de um sentido afetivo em relação ao passado.

É importante enfatizar que os trabalhos com as memórias supõem um outro tempo, "uma terra distante" (FORTUNA, 1997, p. 131), ou seja, o tempo passado, mas as mesmas têm suas âncoras no tempo presente. Portanto, o sujeito que narra o que viveu faz uma narrativa a partir de referenciais do momento presente. A memória coletiva assume, segundo Pollak (1989, p. 11), “a forma de um mito" e, por não mais encontrar ancoragens no presente, busca referências no imaginário do passado. Ou seja, mais uma vez reiteramos a importância de uma análise que indague quem está narrando, qual o lugar de sujeito que ocupa, por que fala, quando fala e para quem dirige sua narrativa. Então, a grande questão que acompanhou este estudo foi a de compreender o que dizem essas narrativas de memória dessas moças e desse rapaz, as coincidências e as possíveis dissonâncias das suas narrativas.

Partimos da convicção que lembrar não é reviver, mas refazer, repensar, construir com imagens e ideias de hoje as experiências do passado. A construção do passado de jovens estudantes - que, pelo pouco tempo de 
vida, em alguns momentos até duvidavam ter memórias para escrever - é condicionada pelo presente, relativizada pela e na situação da qual emergem as lembranças. O PIBID Pedagogia constitui o presente que abre a janela para o passado e nesse sentido é dele que se fala ao realizar a leitura dos memoriais.

Segundo Bastos (2003), escrever e ler memoriais possibilita repensar a prática educativa na perspectiva de que a vida é o lugar da educação e a história de vida o terreno sobre o qual se constrói a formação. É um recurso de reflexão, um processo de leitura diacrônica do mundo, de leitura do processo de construção de si e, por isso, o trabalho de escrita do memorial foi intensamente formativo.

Os memoriais que aqui estão foram escritos por estudantes que desejaram partilhar suas trajetórias e se constituem também como fonte para a História da Educação. Buscamos descobrir o que há de singular, de inédito em cada uma das narrativas, que em conjunto formam uma teia, a teia da vida de estudantes da Licenciatura em Pedagogia que escolheram a docência como futura profissão. Embora cada história aqui relatada teça fios em direção ao passado, são possibilidades de futuro, construídas num presente e, como diz Tecelina (SOUZA, 2002, p. 11), "o que foi tecido é presente".

Nesse percurso de escrita de si, cada autora e autor se deixou revelar. Nesse sentido, é possível compor uma espécie de retrato de cada narrador. Algumas narrativas apresentam um conteúdo intenso, são reflexões densas acerca da própria existência. Algumas são lineares, os acontecimentos escolhidos seguem a sequência cronológica, enquanto outras rompem com a linearidade ao realizar um vai e vem no tempo e ao considerarem a complexidade.

Ao escrever sobre si, cada bolsista apropriou-se de uma parte importante de sua vida. Porém, aparece também a dimensão do coletivo, como uma delas anuncia: "Foi a inserção no grupo que me proporcionou a escrita deste memorial, fazendo me perceber como sujeito constituinte e partícipe da e na história da humanidade". Essa constatação corrobora com a ideia que compartilhamos, pois fazer história é perceber-se como sujeito da história, atuante e capaz de participar do processo de transformação. 


\section{REFERÊNCIAS}

AMADO, J. O grande mentiroso: tradição, veracidade e imaginação em História Oral. Revista História, São Paulo, v. 14, p. 125-136, 1995.

ARENHALDT, R. Vidas em Conexões (in)tensas na UFRGS: o Programa Conexões de Saberes como uma Pedagogia do estar-junto na Universidade. 2012. 254 f. Tese (Doutorado em Educação)-Universidade Federal do Rio Grande do Sul, Porto Alegre, 2012.

ARENHALDT, R.; MARQUES, T. B. I. Memórias e afetos na formação de professores. Pelotas: Editora Universitária UFPel, 2010. (Cadernos PROEJA, n. 1).

BACHELARD, G. A Filosofia do Não; O Novo Espirito Científico. São Paulo: Abril Cultural, 1974. (Os Pensadores, n. XXXVIII).

BASTOS, M. H. Memoriais de professoras: reflexões sobre uma proposta. In: MIGNOT, A. C. V.; CUNHA, M. T. S. (Orgs.). Práticas de memória docente. São Paulo: Cortez, 2003. p. $167-183$

BOSI, E. O tempo vivo da memória: ensaios de psicologia social. São Paulo: Ateliê Editorial, 2003. COORDENAÇÃO DE APERFEIÇOAMENTO DE PESSOAL DE NÍVEL SUPERIOR - CAPES. Diretoria de Educação Básica - DEB. Edital PIBID 2009. Brasília: CAPES, 2009.

FENTRESS, J.; WICKHAM, C. Memória social: novas perspectivas sobre o passado. Lisboa: Teorema, 1992.

FORTUNA, C. As cidades e as identidades: narrativas, patrimônios e memórias. Revista Brasileira de Ciências Sociais, São Paulo, v. 12, n. 33, p. 127-141, fev. 1997.

FOX, M. Guilherme Augusto Araújo Fernandes. Ilustrações de Julie Vivas. São Paulo: Brinque-book, 1995.

LOVISOLO, H. A memória e a formação dos homens. Estudos Históricos, Rio de Janeiro, v. 2, n. 3, p. 16-28, 1989.

MUNDURUKU, D. Em busca de uma ancestralidade brasileira. Revista Fazendo Escola, Alvorada, v. 2, p. 40-42, 2002.

POLLAK, M. Memória, esquecimento e silêncio. Estudos Históricos, Rio de Janeiro, v. 2, n. 3, p. 3-15, 1989.

SANTOS, M. O pesadelo da amnésia coletiva: um estudo sobre os conceitos de memória, tradição e traços do passado. Revista Brasileira de Ciências Sócias, São Paulo, v. 23, n. 8, p. 68-84, out. 1993.

SOUZA, G. Tecelina. Ilustrações de Cristina Biazetto. Porto Alegre: Projeto, 2002.

STEPHANOU, M. Prefácio. Nem uma coisa, sem outra ou nenhumas. (Re)invenções e reminiscências escolares. A modo de prefácio. In: FISCHER, B. T. D. (Org.). Tempos de Escola. São Leopoldo: Oikos; Brasília: Liber Livros, 2012. Memórias v. 3, p. 11-16.

THOMSON, A. Memórias de Anzac: colocando em prática a teoria da memória popular na Austrália. História Oral, São Paulo, v. 4, p. 85-101, jun. 2001.

WEBBER, A. L. et al. Caminhadas de universitários de origem popular. UFRGS. Rio de Janeiro: UFRJ, Pró-Reitoria de Extensão, 2006. 


\section{NOTAS}

${ }^{1}$ Destacamos, em especial, dois temas: o primeiro tratou de aprofundar o entendimento da história e cultura dos povos indígenas, produzindo propostas didáticas desenvolvidas nas escolas parceiras; outro tema que ora nos debruçamos diz respeito à educação patrimonial. 2 Optamos por usar a palavra bolsista no feminino, visto que compõem o grupo 13 moças e um rapaz.

3 As letras das canções foram consultadas em www.terra.com.br/musicas.

${ }^{4}$ Cada bolsista escolheu o nome de uma flor para se identificar neste texto.

Apoio financeiro: CAPES

Recebido: 07/02/2013

Aprovado: 29/04/2013

Contato:

Universidade Federal do Rio Grande do Sul Faculdade de Educação

Programa de Pós-Graduação em Educação Av. Paulo Gama, s/n, prédio 12201, 7 andar CEP $90046-900$

Porto Alegre, RS

Brasil 